\title{
A NEW SPECIES OF MITES OF THE GENUS BDELLA (ACARI, BDELLIDAE) FROM UKRAINE
}

\author{
S. I. Maslov, A. A. Khaustov \\ Nikita Botanical Gardens - National Scientific Center, \\ Yalta, Crimea, 98648 Ukraine \\ E-mail: serdok78@mail.ru; alkhaustov@mail.ru
}

\begin{abstract}
A New Species of Mites of the Genus Bdella (Acari, Bdellidae) from Ukraine. Maslov S. I., Khaustov A. A. Bdella kuznetsovi Maslov et Khaustov, sp. n. is described from storm detritus of Black Sea and Sivash Gulf of the Sea of Azov, Ukraine.
\end{abstract}

Key words: Bdellidae, Bdella, new species, storm detritus, Ukraine.

Новый вид клещей рода Bdella (Acari, Bdellidae) из Украины. Маслов С. И., Хаустов А. А. - Описан Bdella kuznetsovi Maslov et Khaustov, sp. n., обнаруженный в штормовых выбросах Чёрного моря и залива Сиваш Азовского моря из Украины.

Ключевые слова: Bdellidae, Bdella, новый вид, штормовые выбросы, Украина.

\section{Introduction}

The bdellid mite genus Bdella Latreille, 1795 includes about 40 described species (Hernandes et al., 2008) distributed worldwide (Atyeo, 1960; Kuznetsov and Livshits, 1979; Van der Schyff et al., 2005; Wallace, Mahon, 1972). By far, four species of the genus Bdella have been recorded from Ukraine: B. longicornis (Linnaeus, 1758), B. muscorum Ewing, 1909, B. iconica Berlese, 1923, and B. taurica Kuznetsov and Livshits, 1979 (Kuznetsov and Livshits, 1979; Wainstein et al., 1978). Kuznetsov and Livshits (1979) also recorded Bdella mexicana Baker et Balock, 1944 from Crimea but our study of the Crimean specimens of this species revealed that it should be transferred to the genus Hexabdella Van der Schyff, Theron et Ueckermann, 2004.

During the study of mites inhabiting storm detritus on the shores in nature reserves of the Black Sea and Sea of Azov, a new species of the genus Bdella was found. It is described in this paper.

\section{Material and methods}

Mites were collected from storm detritus using Berlese funnels and mounted on slides in Hoyer's medium. The mites were examined under a light microscope with phase contrast. Drawings were made with a camera lucida. The notations of the idiosomal setae follow Grandjean $(1939,1943)$ as adopted for Eleutherengona by Bochkov (2009). The designations of the cheliceral setae follow Grandjean (1947) and that of the subcapitular setae Hernandes et al. (2008). All measurements are given in micrometers $(\mu \mathrm{m})$ for the holotype. The type specimens are deposited in the collection of the Nikita Botanical Gardens - National Scientific Center, Yalta, Ukraine. In the description of the leg chaetotaxy, the following abbreviations were used: asl - pointed solenidion, bsl - blunt-ended solenidion, tr - trichobothrium, sts - simple tactile seta, bts - barbed tactile setae, fam - famulus.

\section{Family Bdellidae Duges, 1834}

Genus Bdella Latreille, 1795

Bdella kuznetsovi Maslov et Khaustov, sp. n. (fig. 1-4)

Type material. holotype o: Ukraine, Crimea, Arabatsky Nature Reserve, storm detritus on shore of

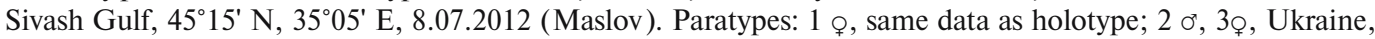
"Lebyazhy Islands" branch of the Crimean Nature Reserve, storm detritus on shore of the Black Sea, $45^{\circ} 51^{`} \mathrm{~N}, 33^{\circ} 29^{`} \mathrm{E}, 7.07 .2012$ (Maslov). 


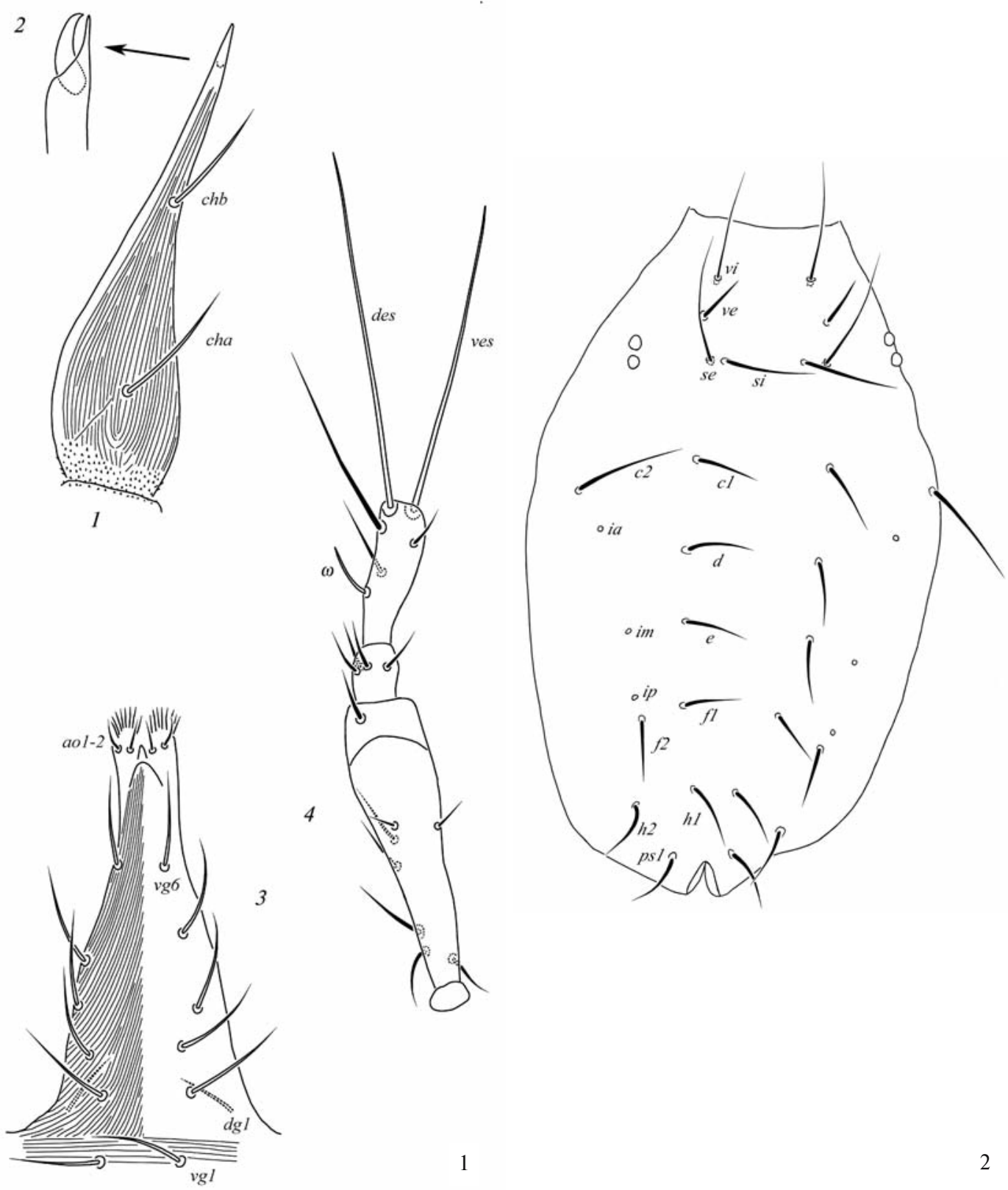

Fig. 1. Bdella kuznetsovi sp. n., o: 1 - chelicerae; 2 - distal end of chelicerae; 3 - subcapitulum; $4-$ palp. Рис. 1. Bdella kuznetsovi sp. n., o: 1 - хелицера; 2 - дистальный конец хелицеры; 3 - субкапитулюм; 4 - пальпа.

Fig. 2. Bdella kuznetsovi sp. n., o: idiosomal dorsum.

Рис. 2. Bdella kuznetsovi sp. n., ơ: дорсальная сторона идиосомы.

Male. Idiosoma 726 long, maximum width 440.

Gnathosoma (fig. 1). Chelicerae dorsally covered by thin longitudinal striae and with two pairs of setae (cha and chb) (fig. 1, 1). Seta cha (56) is slightly shorter than chb (63). Movable digit of chelicerae smooth, curved (fig. 1, 2). Subcapitulum with 6 pairs of ventral setae $(v g 1-v g 6)$, one pair of dorsal setae $(d g 1)$ basally, and two pairs of small adoral setae $($ ao 1-2) (fig. 1, 3). Palp chaetotaxy: trochanter 0 , basifemur 6-7sts, telofemur 
1sts, genu 4sts, tibiotarsus 3sts, 2 eupathidia (des, ves), 1 solenidion ( $\omega$ ) (fig. 1. 4). Length of des 160, ves 132. Length of palpal segments: trochanter 12, basifemur 102, telofemur 33 , genu 28 , tibiotarsus 57 .

Idiosomal dorsum (fig. 2). All setae are smooth. Prodorsum medially with longitudinal striae, but they do not reach beyond setae vi (fig. 3, 1). Weakly developed apodemes present between setae $v i$ and se. Bothridia of setae $v i$ and se with distinct longitudinal striation. Length of setae: vi121, ve 61, si 100. se 146, c1 72, c2 110, $d$ 65, e 68, f1 64, f2 72, h1 32, h2 51, ps1 71, ps2 50, ps3 33.

Idiosomal venter. Genital valves each with 8-9 genital setae (fig. 3, 2). Aggenital setae 9-10 pairs, setae $a g 1$ situated between coxae IV. Amphioid sclerites with 9-10 pairs of eugenital setae (fig. 3, 3), anteriorly with an unpaired wrinkled sac-like gland, and a pair of very large spherical lateral glands.

Legs (fig. 4). Relative length of legs: II $<$ I $<$ III $<$ IV. Chaetotaxy of legs I-IV: coxae 5/6-5/6-6/7-4sts; trochanters: 1-1-2-1sts; basifemora: 8/9-8/9-7-3/4/5sts; telofemora: 6-5/6-6-5/6sts; genua: 6sts, 1asl, 1 bsl - 6sts, 1asl -5 sts, 1asl -6 sts, 1asl; tibiae: $1 \mathrm{tr}, 6 / 7 \mathrm{sts}$, 4asl $-7 \mathrm{sts}, 1 \mathrm{bsl}, 1 \mathrm{asl}-7 \mathrm{sts}$, 1asl $-9 \mathrm{sts}, 1 \mathrm{tr}$; tarsi: 11/12sts, 10bts,
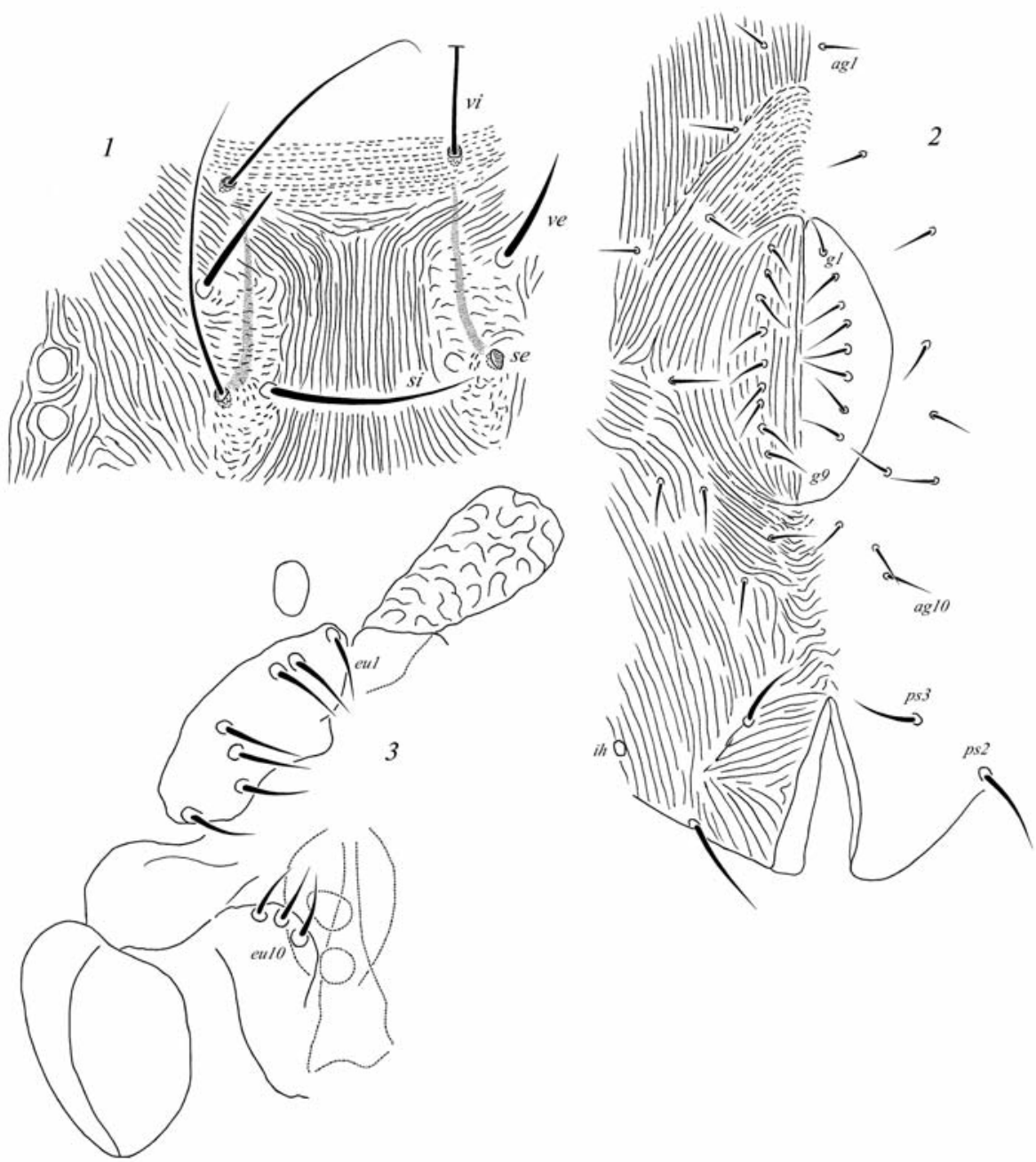

Fig. 3. Bdella kuznetsovi sp. n., o: 1 - prodorsum; 2 - opistosomal venter; 3 - genitalia.

Рис. 3. Bdella kuznetsovi sp. n., o: 1 - продорсум; 2 - вентральная сторона опистосомы; 3 - гениталии. 


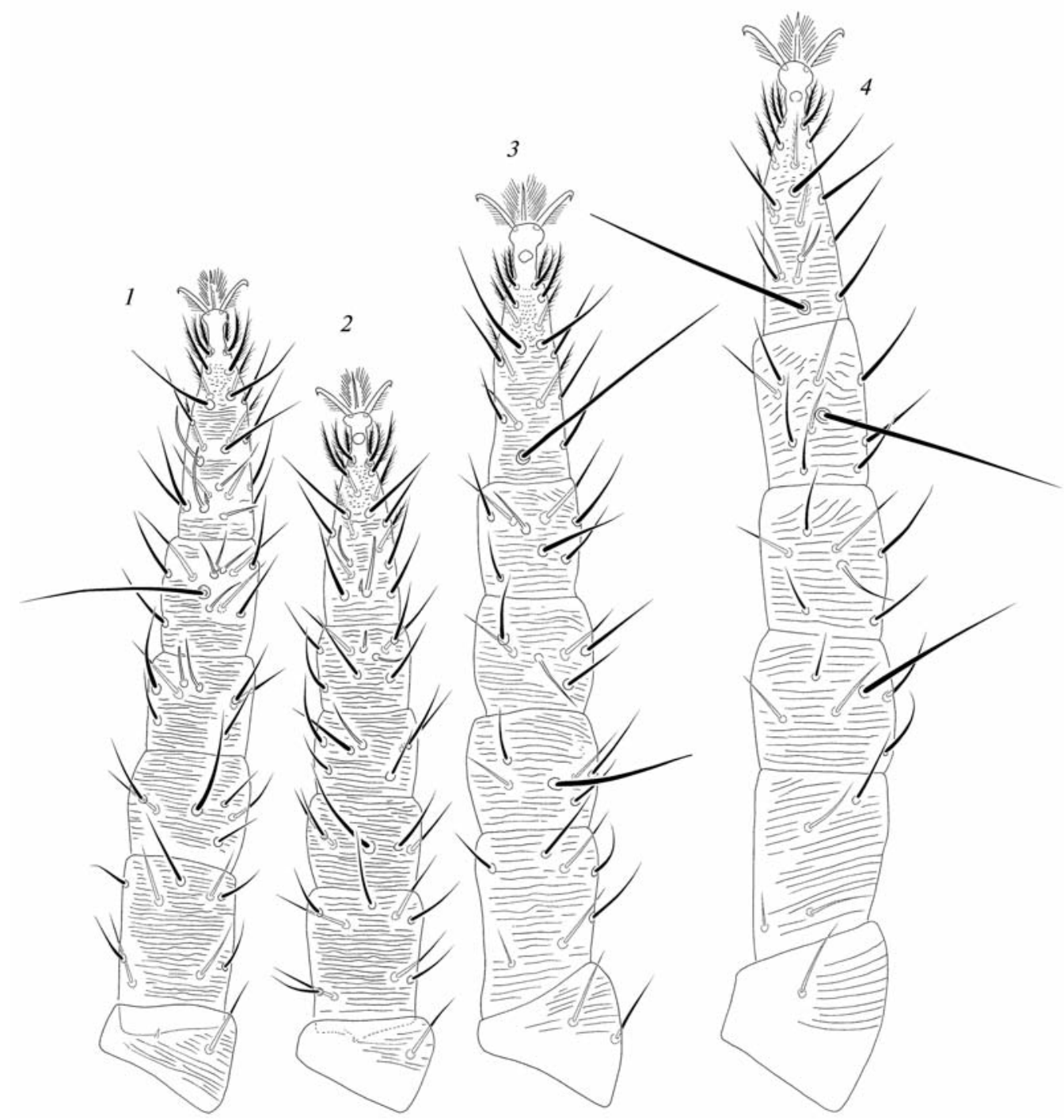

Fig. 4. Bdella kuznetsovi sp. n., o: 1-4 - legs I-IV respectively.

Рис. 4. Bdella kuznetsovi sp. n., о: 1-4- ноги I-IV соответственно.

2asl, 2bsl, 1fam -8 sts, 10bts, 2bsl, 1fam $-8 / 9$ sts, 10bts, 1tr -8 sts, 10bts, 1tr, 1asl. Tarsi I and II with spine-like famulus situated near the base of basal blunt-ended solenidion.

Female similar to male, but differs in being slightly larger and by the presence of a ovipositor. Length of idiosoma 780, width 495.

Etymology. The new species is named in honor of the well-known Ukrainian acarologist, Professor N. N. Kuznetsov for his great contribution to the study of bdellid mites in Ukraine.

Differential diagnosis. The new species can be distinguished by the longitudinal striae medially on prodorsum and weakly developed apodemes only between bases of trichobothria $v i$ and se. It closely resembles Bdella grandjeani Thor, 1931, B. tropica Atyeo, 1960, and B. nylsvieyensis Van der Schyff, Theron and Ueckermann, 2005. It differs from B. nylsvieyensis by the smooth dorsal setae (brushy distally in B. nylsvieyensis); in B. grandjeani the palp basifemur bears 10 setae and setae sci are much shorter than the distance between their bases opposed to only 6-7 setae on basifemur and setae sci, which are longer 
than the distance between their bases in the new species. From B. tropica the new species differs by the presence of 2 solenidia on genu I ( 3 in $B$. tropica) and 2 solenidia on tibia II ( 3 in B. tropica). Among Ukrainian species of Bdella, the new species is very similar to $B$. taurica Kuznetsov and Livshits, 1979, but differs by the presence of prodorsal apodemes between setae $v i$ and se (absent in $B$. taurica), smooth dorsal setae (barbed in $B$. taurica), distinctly longer setae si and by the longitudinal striae on prodorsum not reaching beyond bases of si (reaching beyond bases of si in B. taurica).

Authors thank Dr. E. Ueckermann (Republic of South Africa) for critical reviewing of the manuscript. Authors also thank to A. L. Sergeyenko for technical assistance.

\section{References}

Atyeo $W . T$. A revision of the mite family Bdellidae in North and Central America (Acarina, Prostigmata) // The University of Kansas Science Bulletin. - 1960. - 40, N 8. - P. 345-499.

Bochkov A. V. A review of mites of the parvorder Eleutherengona (Acariformes: Prostigmata) - permanent parasites of mammals // Acarina. - 2009. - Suppl. 1. - P. 1-149.

Grandjean F. Les segments post-larvaire de l'hysterosoma chez les Oribates (Acariens) // Bull. de la Societe Zoologique de France. - 1939. - 64. - P. 273-284.

Grandjean F. Le developpement postlarvaire d' "Anystis" (acarien) // Mémoires du Muséum national d'historire naturelle. N. S. - 1943. - 18, N 2. - P. 33-77.

Grandjean F. L'origine pileuse des mors et la chaetotaxie de la mandibule chez les Acariens actinochitineux // Comptes rendus des séances de l'Academie des Sciences. - 1947. - 224. - P. 1251-1254.

Hernandes F. A., Rodrigo D. D., Reinaldo J. F. F. Two new species of Bdellidae (Acari: Prostigmata) from Brasil // International Journal of Acarology. - 2008. - 34 (3). - P. 259-266.

Kuznetsov N. N., Livshits I. Z. Predatory mites of the Nikita Botanical Gardens (Acariformes: Bdellidae, Cunaxidae, Camerobiidae) // Pests and diseases of forest-parks and fruit plantings in the Crimea. Proceedings of the Nikita Botanical Gardens. - 1979. - 79. - P. 51-105. - Russian : Кузнецов Н. Н., Ливщии И. 3. Хищные клещи Никитского ботанического сада (Acariformes: Bdellidae, Cunaxidae, Camerobiidae).

Van der Schyff J., Theron P. D., Ueckermann E. A. Descriptions of seven new species of the genus Bdella Latreille (Acari: Prostigmata: Bdellidae) from southern Africa and a redescription of B. neograndjeani Meyer et Ryke // African Entomologist. - 2005. - 13, N 1. - P. 221-238.

Wainstein B. A., Kuznetsov N. N., Livshits I. Z., Sosnina E. F. Family Bdellidae // Opredelitel pochvoobitayuschikh kleshchey. Trombidiformes / Ed. M. S. Gilarov. - 1978. - P. 133-143. - Russian : Вайнштейн Б. А., Кузнецов Н. Н., Ливиии И. З., Соснина Е. Ф. Надсемейство Bdelloidea.

Wallace M. M. H., Mahon J. A. The taxonomy and biology of Australian Bdellidae (Acari). I. Subfamilies Bdellinae, Spinibdellinae and Cytinae // Acarologia. - 1972. - 14, N 4. - P. 544-580.

Received 24 October 2012

Accepted 21 November 2012 